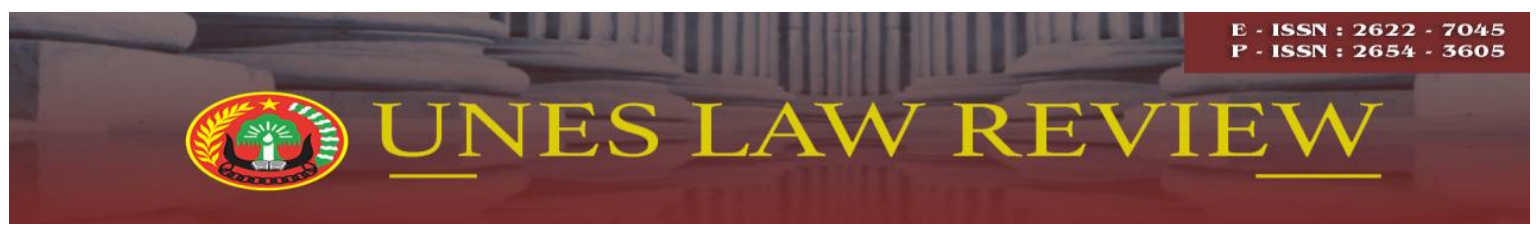

Email: uneslawreview@gmail.com

Online: http://review-unes.com/index.php/law

Volume 2, Issue 4, Juni 2020

\title{
IMPLEMENTASI PRINSIP RESTORATIVE JUSTICE BERDASARKAN VICTIM ORIENTED DALAM DIVERSI GUNA PENYELESAIAN TINDAK PIDANA YANG DILAKUKAN OLEH ANAK (Studi Pada Unit PPA Satreskrim Polres Pesisir Selatan)
}

\author{
Umar Dinata \\ Program Magister Ilmu Hukum, Universitas Ekasakti, Padang, Indonesia \\ Email: umar.dinata999@gmail.com
}

\begin{abstract}
Victim-oriented restorative approaches to diversion have not yet been fully implemented. In practice the results of diversion pay more attention to the interests of the perpetrators than the interests of the victims. The diversion agreement obtained is in the form of a return on losses in the event of a victim; medical and psychosocial rehabilitation; Submission to parents / guardians; participation in education or training in educational institutions or LPKS (Institutions of all forms of agreement above are still oriented to the perpetrators. Recovery of victims is only a stipulated requirement as far as possible to distance the perpetrators from punishment. obstacles in applying the victim-oriented concept of restorative justice, namely: Family attitudes the victim in his participation resolved the case through the concept of Restorative Justice and there was pressure from the investigator against the victim to accept the results of the diversion.
\end{abstract}

Kata Kunci: Diversi, Korban, Pelaku, Anak

\section{PENDAHULUAN}

Korban adalah mereka yang menderita jasmaniah dan rohaniah sebagai akibat tindakan orang lain yang mencari pemenuhan diri sendiri atau orang lain yang bertentangan dengan kepentingan dan hak asasi yang menderita (Bambang Waluyo, 2012:2). Korban kejahatan yang pada dasarnya merupakan pihak yang paling menderita dalam suatu tindak pidana, justru tidak memperoleh perlindungan sebagaimana yang diamanatkan oleh undang-undang. Akibatnya, pada saat pelaku kejahatan telah dijatuhi sanksi pidana oleh pengadilan, kondisi korban kejahatan seperti tidak dipedulikan sama sekali.

Menurut pandangan kriminologi dan hukum pidana, kejahatan adalah konflik antar individu yang menimbulkan kerugian pada korban, masyarakat dan pelanggar sendiri, dimana dari ketiga kelompok tersebut, kepentingan "korban kejahatan" adalah bagian 
utama kejahatan, sebagaimana menurut Andrew Ashworth: "primary an offence against the victim and only secondarily an offence against the wider comunity or state" (Siswanto sunarso, 2012:18).

Akibat sistem peradilan pidana yang cenderung offender oriented, maka viktimologi sebagai studi yang berorientasi terhadap korban memberikan dasar pemikiran diperlukannya konsep penyelesaian perkara diluar sistem peradilan pidana. Solusi yang ditawarkan, yaitu penyelesaian perkara pidana dengan konteks keadilan restoratif (Restorative Justice). Konsep pendekatan Restorative Justice merupakan suatu pendekatan yang lebih menitik beratkan pada kondisi terciptanya keadilan dan keseimbangan bagi korban dan pelaku (Afthonul Afif, 2015:341-350).

Proses diversi yang bersifat offender oriented mengakibatkan pelaku sebagai subyek utama dalam suatu kejahatan sehingga sanksi yang diberikan terkadang menimbulkan rasa ketidakadilan bagi korban. Kejahatan pada umumnya mesti melibatkan dua pihak, yatu pelaku dan korban, walaupun pada kenyataannya ada beberapa kejahatan yang terjadi tanpa adanya korban, dalam artian bahwa pelaku kejahatan itulah yang sekaligus menjadi korban, seperti: perjudian dan penyalahgunaan narkoba (G.Widiartana, 2014:5).

Penyelesaian perkara pidana dengan pendekatan restoratif sudah mulai diterapkan di Indonesia, akan tetapi implementasinya hanya terkait dengan penyelesaian perkara pidana anak. Menurut Pasal 5 ayat (1) Undang-Undang Nomor 11 Tahun 2012 tentang Sistem Peradilan Pidana Anak wajib mengutamakan pendekatan Keadilan Restoratif. Pada praktiknya pendekatan keadilan restoratif sering diterapkan lebih memperhatikan pelaku tndak pidana daripada korban tindak pidana tersebut.

Pada Satreskrim Polres Pesisir Selatan pendekatan restorative dengan victim oriented pada perkara diversi belum sepenuhnya dilakukan. Penyidik lebih memperhatikan kepentingan pelaku daripada kepentingan korban. Sering terjadi korban tidak puas atau merasa terpaksa menerima putusan diversi tersebut. Hal ini dilakukan dengan melibatkan tokoh masyarakat dan tokoh adat namun pelaksanaannya masih terkesan offender oriented dan timbul kesan pada proses ini korban terpaksa menyetujui kesepakatan yang diambil.

Artikel ini kakan membahas tentang implementasi serta kendala kendala yang di hadapi dalam penerapan prinsip restorative justice berdasarkan victim oriented pada 
diversi guna penyelesaian tindak pidana yang dilakukan oleh anak pada tahap penyidikan di Satreskrim Polres Pesisir Selatan.

\section{METODE PENELITIAN}

Spesifikasi penelitian adalah deskriptif analitis, dengan metode pendekatan yuridis normative didukung dengan yuridis empiris. Jenis data yang digunakan adalah data sekunder dan data primer. Data sekunder diperoleh dari studi dokumen dan data primer berasal dari studi lapangan berupa wawancara. Data yang diperoleh kemudian dianalisa secara kualitatif .

\section{HASIL PENELITIAN DAN PEMBAHASAN}

\section{Implementasi Prinsip Restorative Justice Berdasarkan Victim Oriented Pada Diversi Guna Penyelesaian Tindak Pidana Yang Dilakukan Oleh Anak Pada Satreskrim Polres Pesisir Selatan}

Restorative Justice adalah merupakan pengembangan sistem peradilan yang masih baru di Indonesia dalam penyelesaian permasalahan pidana yang menyangkut anak sebagai pelaku tindak pidana. Restorative Justice adalah suatu proses pengalihan dari proses pidana formal ke informal sebagai alernatif terbaik penanganan terhadap anak yang berhadapan dengan hukum dengan semua pihak yang terlibat dalam suatu tindak pidana tertentu bersama-sama memecahkan masalah untuk menangani akibat perbuatan anak di masa yang akan dating (Marlina, 2009:203-204).

Prinsip utama dalam diversi adalah dukungan dan penyembuhan terhadap korban. Berdasarkan penelitian yang dilakukan sebagian besar diversi yang dilakukan oleh Polres Pesisir Selatan menujukan keputusan diversi yang lebih memperhatikan pelaku.

Seorang ahli krimonologi berkebangsaan Inggris, Tony F. Marshall dalam tulisannya "Restorative Justice an Overview" mengatakan: "Restorative Justice is a process whereby all the parties with a stake in a particular offence come together to resolve collectively how to deal with the aftermath of the offence and its implication for the future" (restorative justice adalah sebuah proses di mana para pihak yang berkepentingan dalam pelanggaran tertentu bertemu bersama untuk menyelesaikan persoalan secara bersama sama bagaimana menyelesaikan akibat dari pelanggaran tersebut demi kepentingan masa depan). 
Sementara itu, Marlina menyebutkan dalam bukunya bahwa konsep restorative justice merupakan suatu proses penyelesaian tindakan pelanggaran hukum yang terjadi dilakukan dengan membawa korban dan pelaku (tersangka) bersama-sama duduk dalam satu pertemuan untuk dapat berbicara (Marlina, 2009:180). Sebagaimana pendapat Marlina tersebut dapat dipahami bahwa penyelesaian suatu kasus pidana melalui restorative justice pada dasarnya adalah penyelesaian dengan bersama-sama dilakukan antara pelaku dan korban dalam sebuah forum. Pengertian-pengertian tersebut menjelaskan bahwa dalam keadilan restoratif, yang diutamakan bukanlah penjatuhan hukuman kepada pelaku pidana, melainkan bagaimana pelaku dapat bertanggung jawab terhadap perbuatan pidana yang dilakukan. Pemahaman ini menunjukan bahwa perhatian diversi masih berorientasi kepada pelaku. Putusan yang diambil pada diversi lebih mempertimbangkan kondisi pelaku sebagai anak, tidak mempertimbangkan kerugian yang dialami korban, serta bagaimana korban dapat memperoleh keadilan. Hingga keadaan dapat pulih seperti semula. Tujuan utama dari keadilan restoratif yaitu terciptanya peradilan yang adil. Di samping itu, diharapkan para pihak, baik pelaku, korban, maupun masyarakat berperan besar di dalamnya. Korban diharapkan memperoleh kompensasi yang sesuai dan disepakati bersama dengan pelaku untuk mengganti kerugian dan mengurangi penderitaan yang dialami.

Unsur utama dari restorative justice yaitu kerelaan dan partisipasi dari korban, pelaku dan masyarakat dalam melakukan perbaikan atas tindak pidana yang terjadi juga merupakan ciri dari hukum adat. Pada kenyataan yang ada dalam masyarakat Indonesia mengenai fungsionalisasi lembaga musyawarah sebagai bagian dari mekanisme yang dipilih untuk menyelesaian perkara pidana. Musyawarah baik yang diselenggarakan oleh pelaku dan korban sendiri, atau dengan melibatkan institusi kepolisian atau kejaksaan, atau dengan melalui lembaga adat memperlihatkan (Sholeh Soeaidy dan Zulkhair, 2001:22).

Penyelesaian masalah termasuk di dalamnya adalah tindak pidana melalui musyawarah merupakan pola pikir yang terangkum dalam keadilan restoratif sebagaimana didefiniskan di atas. Karenanya tanpa mengabaikan mekanisme yang bekerja dalam sistem hukum formal, mekanisme penyelesaian melalui lembaga musyawarah pun bekerja dalam masyarakat. Dalam pelbagai asas dan model pendekatan restorative justice, proses dialog antara pelaku dan korban merupakan moral dasar dan bagian terpenting dari penerapan 
keadilan ini. Dialog langsung antara pelaku dan korban menjadikan korban dapat mengungkapkan apa yang dirasakannya, mengemukakan harapan akan terpenuhinya hakhak dan keinginan-keinginan dari suatu penyelesaian perkara pidana. Melalui proses dialog juga pelaku diharapkan tergugah hatinya untuk mengoreksi diri, menyadari kesalahannya dan menerima tanggungjawab sebagai konsekuensi dari tindak pidana yang dilakukan dengan penuh kesadaran. Dari proses dialog ini pula masyarakat dapat turut serta berpartisipasi dalam mewujudkan hasil kesepakatan dan memantau pelaksanaannya.

Dalam konsep mediasi proses dialog dikenal sebagai media komunikasi yang menjadi modal utama penyelenggaraan lembaga mediasi. Keseluruhan proses itulah yang dapat ditemui baik dalam model penyelenggaraan restorative justice seperti: (Setya Wahyudi, 2011:35)

a. Victim Offender Mediation (VOM).

Mediasi antara pelaku dan korban) yaitu suatu forum yang mendorong adanya pertemuan antara pelaku dan korban yang dibantu oleh mediator sebagai koordinator dan fasilitator dalam pertemuan tersebut.

b. Conferencing yaitu suatu forum yang sama dengan VOM, namun dalam bentuk ini terdapat perbedaan yaitu pelibatan penyelesaian bukan hanya melibatkan pelaku dan korban langsung (primary victim), tetapi juga korban tidak langsung (secondary victim), seperti keluarga atau kawan dekat korban serta keluarga dan kawan dekat pelaku. Adapun alasan pelibatan para pihak tersebut adalah karena mereka mungkin terkena dampak baik langsung ataupun tidak langsung atas tindak pidana yang terjadi atau mereka memiliki kepedulian yang tinggi dan kepentingan akan hasil dari musyawarah, serta mereka juga dapat berpartisipasi dalam mengupayakan keberhasilan proses dan tujuan akhirnya.

c. Circles, suatu model penerapan restorative justice yang pelibatannya paling luas di bandingkan dengan dua bentuk se belumnya, yaitu forum yang bukan hanya korban, pelaku, keluarga atau mediator saja tapi juga anggota masyarakat yang merasa berkepentingan dengan perkara tersebut.

Ketiga model dasar dari bentuk penerapan pendekatan restoratif justice tersebut pada dasarnya merupakan bentuk-bentuk yang menjadi variasi dari model dialog yang merupakan pelaksanaan dari bentuk musyawarah dan mufakat. Dari nilai dasar inilah restorative justice sebagai implementasi dari nilai dasar yang ada dalam masyarakat Indonesia memiliki pondasi nilai yang kuat. Sayangnya penyelesaian model ini belum memiliki justifikasi perundang-undangan yang jelas.

Perhatian khusus terhadap proses keadilan restoratif di kalangan anak sangat diperlukan, karena ada hal-hal yang signifikan untuk menjadi fokus pengaturan yang 
memerlukan peran aktif masyarakat, pelaku, dan korban kejahatan, termasuk masyarakat terdampak dalam proses keadilan retoratif.

Pendekatan keadilan restoratif menyediakan kesempatan dan kemungkinan bagi korban kejahatan untuk memperoleh reparasi, rasa aman, memungkinkan pelaku untuk memahami sebab dan akibat perilakunya dan bertanggungjawab dengan cara yang berarti dan memungkinkan masyarakat untuk memahami sebab utama terjadinya kejahatan, untuk memajukan kesejahteraan masyarakat dan mencegah kejahatan. Keadilan restoratif menampilkan serangkaian tindakan yang fleksibel yang dapat disesuaikan dengan system peradilan pidana yang berlaku dan secara komplementer dilakukan dengan mempertimbangkan kondisi hukum, sosial dan budaya. Pendayagunaan keadilan restoratif tidak akan merugikan hak negara untuk menuntut pelaku tindak pidana.

Kesepakatan diversi dilakukan oleh penyidik atas rekomendasi pembimbing kemasyarakatan di wilayah hukum Polres Pesisir Selatan dapat berbentuk;

1) pengembalian kerugian dalam hal ada korban;

2) rehabilitas medis dan psikososial;

3) Penyerahan kembali kepada orang tua/Wali;

4) keikutsertakan dalam pendidikan atau pelatihan di lembaga pendidikan atau LPKS

Kesemua bentuk kesepakatan diatas masih berorientasi kepada pelaku. Pemulihan korban hanya merupakan sebuah persyaratan yang ditetapkan sedapat mungkin menjauhkan pelaku dari pemidanaan. Korban merasakan hasil putusan diversi terpaksa disetujui karena merasakan ada tekanan dari aparat penegak hukum dan petugas bapas. Korban merasa putusan belum dapat memulihkan kerugian yang dialaminya.

\section{Kendala Kendala Yang Di Hadapi Dalam Implementasi Prinsip Restorative Justice Berdasarkan Victim Oriented}

Keterlibatan korban, masyarakat yang terdampak dan pelaku, perlu pula ditekankan betapa pentingnya keterlibatan tenaga profesional yang terlatih dan yang memiliki keahlian khusus tentang perilaku remaja dalam proses keadilan restoratif (juvenile justice professional). Perannya antara lain: memfasilitasi mediasi, menentukan tempat-tempat tertentu yang berharga bagi masyarakat seandainya kewajiban pelayanan masyarakat (community service) harus dilakukan oleh pelaku, mengembangkan kelompok empati dan panel korban, mengorganisasikan panel; masyarakat, lembaga atau komite yang berdiskusi 
dengan pelaku untuk kepentingan korban, masyarakat dan pelaku, memfasilitasi proses permintaan maaf pelaku pada korban.

Restorative Justice dalam pelaksanaannya, terdapat beberapa kendala-kendala dalam penerapan konsep restorative justice yang berorientasi kepada korban yaitu:

1. Restorative Justice hanya bisa diterapkan pada pelaku yang mengakui perbuatannya,

2. Korban yang menolak untuk menyetujui hasil kesepakatan

3. Pemahaman pelaku, korban dan masyarakat yang tidak sama tentang tujuan diversi.

4. Sikap keluarga korban dalam partisipasinya menyelesaikan perkara melalui konsep Restorative Justice.

5. Adanya tekanan dari penyidik sebagai fasilitaor pada proses diversi terhadap korban agar mau menerima hasil diversi.

Melihat terdapat berbagai macam kendala-kendala dalam penerapan Restorative Justice secara umum seperti di atas. Kasus yang menjadi studi kasus dalam penelitian ini, tidak ditemukan kendala-kendala yang berarti. Mulai dari aspek hukum yang sudah mengatur untuk dilakukan Keadilan Restorative dalam menangani kasus tindak pidana dengan anak (Pasal 5 Undang-undang Nomor 11 Tahun 2012 tentang Sistem Peradilan Pidana Anak) dan dari Mahkamah Agung juga menerbitkan PERMA Nomor 4 Tahun 2014 tentang pedoman pelaksanaan Diversi Sistem Peradilan Pidana Anak. Serta dari aspek Penegak hukumnya sendiri juga dalam menangani kasus tersebut tidak menggunakan toga dan seragam kepolisian lengkap karena itu akan mempengaruhi psikologis si anak tersebut. Lalu dari aspek Sarana dan Prasarana, pihak kepolisian sudah menyiapkan ruang tersendiri untuk memproses anak yang berhadapan dengan hukum secara terpisah dengan yang lain.

Restorative Justice sangat kental sekali dengan kultur masyarakat Indonesia yang sangat kekeluargaan. Lalu dari aspek Masyarakat yang mempengaruhi, dari Pihak Masyarakat sendiri mendukung penuh sistem Restorative justice ini dengan bisa dilihat dengan ikut sertanya perwakilan masyarakat saat proses Restorative berlangsung. Sehingga penerapan dari Restorative Justice sendiri sudah berlangsung cukup baik.

Penyelesaian tindak pidana yang dilakukan oleh anak dengan kebijakan diversi dan restorative justice membawa partisipasi masyarakat dan mediator sebagai salah satu komponen penting selain aparat penegak hukum sistem peradilan pidana. Peran masyarakat disini adalah memberikan aspirasinya dalam pelaksanaan proses restorative 
justice yaitu dengan mengusahakan agar dapat mengembalikan tatanan masyarakat yang terganggu akibat pelanggaran yang dilakukan pelaku.

Hasil dari restorative justice adalah mengembalikan korban dan pelaku ke dalam wadahnya semula yaitu keluarga dan lingkungannya. Salah satu hasil dari restorative justice adalah pelaku memberikan tanggungjawab langsung kepada korban dalam bentuk ganti rugi atau pertanggungjawaban lainnya selain pidana. Setelah dilakukan penandatanganan kesepakatan maka pelaku harus melaksanakan semua kesepakatan tersebut dengan pengawasan dari masyarakat. Sementara itu korban berhak mendapat ganti rugi dan penyembuhan dari pelaku atas kesakitan, penderitaan atau kerugian yang diterimanya. Salah satu isu penting yang harus diperhatikan dari hasil diversi dan restorative justice ini adalah hasil dari proses ini mempunyai beberapa akibat terutama perilaku pelaku setelah pertanggungjawabannya selesai dilaksanakan (DS Dewi dan Fatahillah A.Syukur, 2011:40).

Restoratif justice banyak diberikan makna, definisi atau pengertiannya oleh pakarpakar hukum. Pada prinsipnya keadilan restoratif itu adalah konsep pemikiran yang tidak hanya merespon pengembangan Sistem Peradilan Pidana dengan menitikberatkan pada kebutuhan si pelaku tetapi juga pelibatan korban dan masyarakat yang dirasa tersisihkan dengan mekanisme yang bekerja pada sistem peradilan pidana saat ini.

Restoratif yaitu partisipasi penuh dan konsensus, pengembalian kerusakan atau kerugian, pertanggungjawaban yang penuh dari pelaku, penyatuan kembali pelaku sebagai warga masyarakatnya dan kekuatan pencegahan supaya tindakan kejahatan tidak terulang kembali. Dengan demikian, pemidanaan restoratif dapat membantu sistem peradilan konvensional mengurangi tingkat kejahatan, menghemat sumberdaya yang berharga dan memperkuat sistem peradilan di mata publik. Pada saat ini baru diterapkan pada system peradilan pidana anak.

Restoratif justice ini memiliki hambatan-hambatan yaitu memasukkan peraturan restoratif justice dalam sistem hukum secara lengkap, seringnya terjadi re-offending atau pelanggaran kembali oleh pelaku yang telah menjalani restoratif justice, keberhasilan dari proses restoratif justice sangat tergantung dari pihak keluarga yang menjadi tempat anak dikembalikan, sangat sulit untuk menghindarkan anak dari pemidanaan secara retributive justice apabila melakukan pelanggaran yang sangat serius. 
Banyak orang yang menganggap restoratif justice adalah keadilan yang lunak (soft justice). Restoratif justice dapat dilaksanakan secara teori untuk semua kasus tapi sangat sulit dalam praktiknya untuk kasus-kasus yang serius. Lalu adanya pemahaman masyarakat tentang proses restoratif justice dan tujuannya serta kepercayaan terhadap petugas pelaksanannya, kemampuan mediator sangat mempengaruhi keberhasilan proses restoratif justice dan petugas yang terlalu campur tangan dalam keputusan.

\section{PENUTUP}

Implementasi Prinsip Restorative Justice Berdasarkan Victim Oriented Pada Diversi Guna Penyelesaian Tindak Pidana Yang Dilakukan Oleh Anak Pada Satreskrim Polres Pesisir Selatan adalah memenuhi prinsip dasar diversi yaitu dukungan dan penyembuhan terhadap korban. Berdasarkan penelitian yang dilakukan sebagian besar diversi yang dilakukan oleh Polres Pesisir Selatan menujukan keputusan diversi yang lebih memperhatikan pelaku. Kendala Kendala Yang Di Hadapi Dalam Implementasi Prinsip Restorative Justice Berdasarkan Victim Oriented Pada Diversi Guna Penyelesaian Tindak Pidana Yang Dilakukan Oleh Anak Di Satreskrim Polres Pesisir Selatan antara lain Korban yang menolak untuk menyetujui hasil kesepakatan, Pemahaman pelaku, korban dan masyarakat yang tidak sama tentang tujuan diversi. Sikap keluarga korban dalam partisipasinya menyelesaikan perkara melalui konsep Restorative Justice dan Adanya tekanan dari penyidik sebagai fasilitaor pada proses diversi terhadap korban agar mau menerima hasil diversi.

\section{DAFTAR PUSTAKA}

\section{Buku Teks:}

Afthonul Afif, Pemaafan, Rekonsiliasi dan Restoraive Justice, Pustaka Pelajar, Yogyakarta, 2015

Bambang Waluyo, Viktimologi perlindungan korban dan saksi, Sinar Grafika, Jakarta, 2012

DS Dewi dan Fatahillah A.Syukur, MEDIASI PENAL : Penerapan Restoratif Justice di Pengadilan Anak Indonesia, Indie Publishing, Depok, cetakan 1, 2011

G.Widiartana, Viktimologi Perspektif Korban dalam Penanggulangan Kejahatan, Universitas Atma Jaya, Yogyakarta, 2014 
Marlina, Peradilan Pidana Anak di Indonesia, Pengembangan Konsep Diversi dan Restorative Justice, Cet I, Refika Aditama, Bandung, 2009

Siswanto sunarso, Viktimologi dalam system peradilan pidana, Sinar grafika, Jakarta, 2012

Sholeh Soeaidy dan Zulkhair, Dasar Hukum Perlindungan Anak, cet. ke-1, Novindo Pustaka Mandiri, Jakarta, 2001

Setya Wahyudi, Implementasi Ide Diversi Dalam Pembentukan Sistem Peradilan Pidana Anak di Indonesia. Genta Publishing, Yogyakarta, 2011

\section{Peraturan Undang-Undang :}

Undang-Undang Nomor 11 Tahun 2012 tentang Sistem Peradilan Pidana Anak 